\title{
COMPARISON OF FRACTIONATION METHODS FOR SOIL ORGANIC MATTER ${ }^{14}$ C ANALYSIS
}

\author{
SUSAN E. TRUMBORE and SHUHUI ZHENG
}

Department of Earth System Science, University of California, Irvine, CA 92697-3100 USA

\begin{abstract}
C}$ measurements provide a useful test for determining the degree to which chemical and physical fractionation of soil organic matter (SOM) are successful in separating labile and refractory organic matter components. Results from AMS measurements of fractionated SOM made as part of several projects are summarized here, together with suggestions for standardization of fractionation procedures. Although no single fractionation method will unequivocally separate SOM into components cycling on annual, decadal and millennial time scales, a combination of physical (density separation or sieving) and chemical separation methods (combined acid and base hydrolysis) provides useful constraints for models of soil carbon dynamics in several soil types.
\end{abstract}

\section{INTRODUCTION}

Models describing the dynamics of accumulation and turnover of organic carbon generally recognize components of soil organic matter (SOM) that turn over on annual (active), decadal (slow) and centennial to millennial (passive) time scales (Jenkinson and Raynor 1977; O'Brien and Stout 1978; Parton et al. 1987; Jenkinson, Adams and Wild 1991; Potter et al. 1993; Townsend, Vitousek and Trumbore 1995; Schimel et al. 1994). Although these concepts have proven useful in explaining the magnitude and timing of changes in SOM following a perturbation such as land clearing for cultivation (Parton et al. 1987; Cambardella and Elliott 1993; Davidson and Ackerman 1993; Schimel et al. 1994), no recognized method now exists for determining how to apportion SOM into compartments that turn over on different time scales. To be useful for dividing SOM into components for ecosystem modeling, a procedure must determine both the pool sizes and turnover rates.

Two methods are presently in use to partition SOM into active, slow and passive pools. The first models the observed increase of ${ }^{14} \mathrm{C}$ during the $30 \mathrm{yr}$ since the end of atmospheric weapons testing, using additional constraints derived from knowledge of carbon inputs to the system (O'Brien and Stout 1978; Harkness, Harrison and Bacon 1986; Balesdent 1987; Scharpenseel et al. 1989; Trumbore, Vogel and Southon 1989; Vitorello et al. 1989; Jenkinson, Adams and Wild 1991; Harrison, Broecker and Bonani 1993; Trumbore 1993; Townsend, Vitousek and Trumbore 1995; Trumbore, Chadwick and Amundson 1996). The second relies on physical and/or chemical fractionation methods to separate SOM into pools that turn over on different time scales (Paul et al. 1964; Campbell et al. 1967; Scharpenseel, Ronzani and Pietig 1968; Martel and Paul 1974; Goh et al. 1976; Goh, Stout and Rafter 1977; Anderson and Paul 1984; Goh, Stout and O'Brien 1984; Scharpenseel et al. 1989; Trumbore, Vogel and Southon 1989; Trumbore, Bonani and Wölfli 1990; Scharpenseel and BeckerHeidmann 1992).

Radiocarbon measurements of pre-bomb SOM fractions are interpreted as indicative of their turnover rates, though this can cause serious overestimation of the turnover time in soils collected before 1963 (Balesdent 1987; Trumbore 1993; Trumbore and Druffel 1995). A test of the efficiency of any fractionation method at isolating a relatively homogeneous (in terms of turnover) organic matter pool is a comparison of the observed ${ }^{14} \mathrm{C}$ increase since atmospheric weapons testing (Goh, Stout and O'Brien 1984; Balesdent 1987; Trumbore, Vogel and Southon 1989; Trumbore 1993). These tests have shown that, although no fractionation method is completely successful, separation of organic matter by density, followed by hydrolysis in $6 \mathrm{~N} \mathrm{HCl}$, does leave a residual collection of compounds, which, on average, turn over more slowly than the hydrolyzed portions of SOM (Campbell et al. 1967; Scharpenseel, Ronzani and Pietig 1968; Martel and Paul 1974; Goh et al. 1976; 
Goh, Stout and Rafter 1977; Anderson and Paul 1984; Goh et al. 1984; Trumbore, Vogel and Southon 1989; Trumbore, Bonani and Wölfli 1990; Scharpenseel and Becker-Heidmann 1992; Trumbore 1993; Trumbore, Chadwick and Amundson 1996).

Here we compare measurements of ${ }^{14} \mathrm{C}$ made of SOM fractionated using different physical and chemical separation methods. We analyzed both archived (pre-bomb) and contemporary soil samples. The implications of these data for soil carbon cycling are discussed in other publications (see Table 1 for references).

TABLE 1. Summary of Characteristics of Soils Analyzed in the Fractionation Study

\begin{tabular}{|c|c|c|c|c|c|c|c|c|}
\hline Sample & Location & $\begin{array}{c}\text { Year } \\
\text { collected }\end{array}$ & $\begin{array}{c}\text { Clay } \\
\text { content }\end{array}$ & $\begin{array}{l}\text { Soil order/ } \\
\text { horizon }\end{array}$ & $\begin{array}{l}\text { Vegetation/ } \\
\text { climate }\end{array}$ & $\begin{array}{l}\text { Parent } \\
\text { material }\end{array}$ & $\begin{array}{c}\text { Depth } \\
\text { interval }(\mathrm{cm})\end{array}$ & Ref.* \\
\hline BS-7 & $\begin{array}{l}\text { Paragominas, } \\
\text { Brazil }\end{array}$ & 1992 & $>85 \%$ & Oxisol/A & Tropical forest & $\begin{array}{l}\text { Kaolinitic } \\
\text { sediments }\end{array}$ & $30-35$ & 1 \\
\hline BS-9 & Pará, Brazil & 1992 & $>85 \%$ & Oxisol/ B & Tropical forest & $\begin{array}{l}\text { Kaolinitic } \\
\text { sediments }\end{array}$ & $100-105$ & 1 \\
\hline $\mathrm{H}-13$ & $\begin{array}{l}\text { Lapahoehoe, } \\
\text { Hawaii }\end{array}$ & 1992 & ND & Andisol/ A & Tropical pasture & $\begin{array}{l}\text { Volcanic ash } \\
(15-25 \mathrm{ka})\end{array}$ & $0-10$ & 2 \\
\hline H-15 & $\begin{array}{l}\text { Lapahoehoe, } \\
\text { Hawaii }\end{array}$ & 1992 & ND & Andisol/ B & Tropical pasture & $\begin{array}{l}\text { Volcanic ash } \\
(15-25 \mathrm{ka})\end{array}$ & 40 & 2 \\
\hline NS-11 & $\begin{array}{l}\text { Shaver Lake, } \\
\text { California }\end{array}$ & 1992 & $7-8 \%$ & Ultisol/ A & $\begin{array}{l}\text { Dry temperate } \\
\text { forest }\end{array}$ & Granodiorite & $5-10$ & 3 \\
\hline NS-13 & $\begin{array}{l}\text { Shaver Lake, } \\
\text { California }\end{array}$ & 1992 & $7-8 \%$ & Ultisol/ B & $\begin{array}{l}\text { Dry temperate } \\
\text { forest }\end{array}$ & Granodiorite & $20-40$ & 3 \\
\hline OS-9 & $\begin{array}{l}\text { Shaver Lake, } \\
\text { California }\end{array}$ & 1959 & $7-8 \%$ & Ultisol/ A & $\begin{array}{l}\text { Dry temperate } \\
\text { forest }\end{array}$ & Granodiorite & $0-15$ & 3 \\
\hline OS-10 & $\begin{array}{l}\text { Shaver Lake, } \\
\text { California }\end{array}$ & 1959 & $7-8 \%$ & Ultisol/ B & $\begin{array}{l}\text { Dry temperate } \\
\text { forest }\end{array}$ & Granodiorite & $15-58$ & 3 \\
\hline A1-52 & Michigan & 1992 & $<2 \%$ & Anspodosol/B & $\begin{array}{l}\text { Moist temperate } \\
\text { forest }\end{array}$ & $\begin{array}{l}\text { Beach sand, } \\
3 \mathrm{ka}\end{array}$ & 52 & 4 \\
\hline B1-56 & Michigan & 1992 & $<2 \%$ & Anspodosol/B & $\begin{array}{l}\text { Moist temperate } \\
\text { forest }\end{array}$ & $\begin{array}{l}\text { Beach sand, } \\
10 \mathrm{ka}\end{array}$ & 56 & 4 \\
\hline
\end{tabular}

* References:

1. Trumbore et al. (1995)

2. Townsend, Vitousek and Trumbore (1995)

3. Trumbore, Chadwick and Amundson (1996)

4. Barrett and Schaetzl (1992)

\section{METHODS}

\section{Summary of Fractionation Methods}

All samples are sieved to remove components $>2 \mathrm{~mm}$. Chemical and density separation procedures have been described before (Trumbore, Vogel and Southon 1989; Trumbore 1993), and are summarized in Figure 1. Three fractionation techniques are used: separation by density, chemical extraction using acids and bases, and separation by size.

\section{Density Separation}

The density separation extracts organic matter of low density $\left(<1.6-2.0 \mathrm{~g} \mathrm{~cm}^{-3}\right)$ by flotation in a heavy liquid. The low-density material consists of plant matter and charcoal (Sollins, Spycher and 
Topik 1983; Spycher, Sollins and Rose 1983). Dense fractions contain mineral-associated organic matter, and some microbial cell debris (Sollins, Spycher and Topik 1983; Spycher, Sollins and Rose 1983). In general, the low-density material has higher ${ }^{14} \mathrm{C}$ values and turns over more rapidly than much of the SOM. Charcoal may be isolated by dissolving other low-density material (except pollen) by treatment with strong acids and bases (Hammond et al. 1991; Gillespie et al. 1992a; Gillespie et al. 1992b).

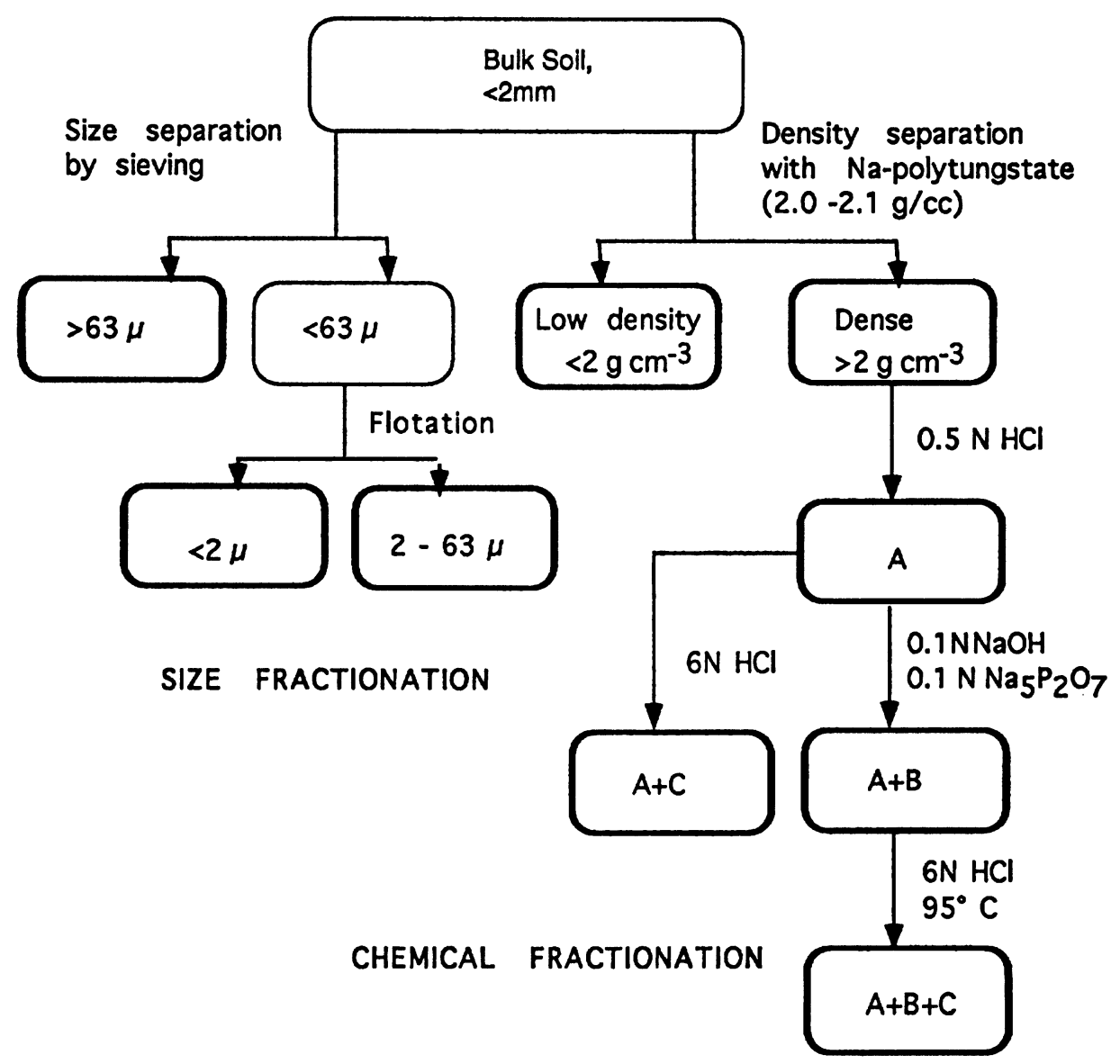

Fig. 1. Fractionation scheme used for samples in this study. See text for details of procedures and explanation of abbreviations.

\section{Chemical Fractionation}

Operationally defined fractionation procedures for SOM often rely on extraction using acids and bases. More labile components are hypothesized to be soluble, leaving behind more refractory (and therefore more ${ }^{14} \mathrm{C}$-depleted) constituents. These chemical extraction procedures will also affect soil mineral content and can cause changes in SOM chemistry and structure. Extraction with Na-pyrophosphate $\left(\mathrm{Na}_{4} \mathrm{P}_{2} \mathrm{O}_{7} \cdot 10 \mathrm{H}_{2} \mathrm{O}\right)$ and $6 \mathrm{~N} \mathrm{HCl}$ will dissolved sesquioxide minerals and remove organic matter complexed with iron and aluminum, and heating SOM in strong acid can cause condensation reactions. The data presented here compare the ${ }^{14} \mathrm{C}$ content of residues after hydrolysis in acid $(\mathrm{HCl})$ 
of varying strength, and in base (NaOH-Na-pyrophosphate). Because the extraction of fresh plant material by these techniques leaves a residue (Ertel and Hedges 1984), we chose to perform acid and base hydrolysis on SOM that has been separated previously by density, and to extract only the denser portion of the soil. For organic-rich Andisol samples, we extracted the bulk soil (as nearly all had densities $>2.1 \mathrm{~g} \mathrm{~cm}^{-3}$ ). Soils developed on basic volcanic rock and containing minerals like allophane and imogolite should employ lower density liquids than we used for improved separation of mineral and organic constituents (Sollins, Spycher and Topik 1983; Spycher, Sollins and Rose 1983).

\section{Size Separation}

Recent research has tied the dynamics of decadal-cycling SOM to different size fractions (Cambardella and Elliott 1993, 1994), which has led to speculation about the role of soil aggregates in limiting the decomposition of reactive SOM constituents by physically protecting organic matter from soil microbial activity (Oades 1993). In addition, the limited measurements of ${ }^{14} \mathrm{C}$ in size-fractionated organic matter available from the literature (Anderson and Paul 1984) suggest a relation between the size of soil-associated organic material and stability of associated organic matter. Recently, Mayer (1994) has shown that organic matter content is related to surface area in many soils and sediments. If organic matter is protected by stabilization on clay surfaces, we might expect it to have lower ${ }^{14} \mathrm{C}$ values than organic matter, which is more available for microbial consumption.

For the size separation, we used the $<2$-mm sieved samples, without prior density separation. We measured the ${ }^{14} \mathrm{C}$ content of three size fractions: $<2 \mathrm{~mm}$ but $>63 \mu,<63 \mu$ but $>2 \mu$, and $<2 \mu$. The largest fraction was separated by dry sieving; the fractions $>$ and $<2 \mu$ were separated by settling from a suspension (Folk 1961). This procedure breaks apart soil aggregates.

\section{Carbon and ${ }^{14} \mathrm{C}$ Measurements}

Percent carbon data were determined by $\mathrm{CO}_{2}$ evolution on in-vacuo combustion at $900^{\circ} \mathrm{C}$ with cupric oxide wire (Buchanan and Corcoran 1959 ). ${ }^{14} \mathrm{C}$ analyses were made by accelerator mass spectrometry (AMS) at the Center for AMS, Lawrence Livermore Laboratory, Livermore, California (Southon et al. 1992). Graphite targets for AMS measurement were prepared from the purified $\mathrm{CO}_{2}$ using the sealed-tube, zinc reduction method modified from Vogel (1992). ${ }^{14} \mathrm{C}$ data are reported as $\Delta^{14} \mathrm{C}$, the per mil difference in ${ }^{14} \mathrm{C} /{ }^{12} \mathrm{C}$ ratio between the sample and an absolute standard (oxalic acid decay-corrected to 1950) (Stuiver and Polach 1977; Donahue, Linick and Jull 1990). $\delta^{13} \mathrm{C}$ values used to correct for mass-dependent fractionation effects were assumed to be $-25 \%$ for all samples, as all sites had predominantly $\mathrm{C}_{3}$ vegetation.

\section{Nomenclature}

We adopt a shorthand for describing the fractionation treatment experienced by a sample. The descriptors, denoted in Figure 1, are defined as follows:

BS = bulk soil. Due the expense of AMS measurements, we often rely on measurements of the constituent fractions to derive a bulk soil ${ }^{14} \mathrm{C}$ number by mass balance.

$\mathrm{LD}=$ low-density fraction $\left(<2.0\right.$ to $\left.2.1 \mathrm{~g} \mathrm{~cm}^{-3}\right)$.

$\mathrm{HD}=$ dense fraction $\left(>2.0\right.$ to $\left.2.1 \mathrm{~g} \mathrm{~cm}^{-3}\right)$.

All chemical fractionation procedures are performed on the HD fraction, and the data associated with them refers to the residue after a given chemical separation procedure. A refers to acid hydrolysis at room temperature in $0.5 \mathrm{~N} \mathrm{HCl}$; B refers to extraction with $0.1 \mathrm{~N} \mathrm{NaOH}-0.1 \mathrm{~N}$ sodium pyrophospate; $\mathrm{C}$ refers to hydrolysis in $6 \mathrm{~N} \mathrm{HCl}$ at $95^{\circ} \mathrm{C}$. Often, we show data derived from the residue 
of a combination of chemical fractionation procedures: for example, $A+B+C$ refers to the residue after sequential hydrolysis in $0.5 \mathrm{~N}$ acid, $0.1 \mathrm{~N} \mathrm{NaOH}$ and $6 \mathrm{~N} \mathrm{HCl}$. When performing these procedures, the residue after each extraction step is rinsed thoroughly in distilled $\mathrm{H}_{2} \mathrm{O}$ before moving on to the next procedure.

\section{Samples}

We present here summaries of fractionation for several different kinds of soils. Table 1 summarizes data related to soil classification and site-specific characteristics, such as climate and parent material. References discussing the carbon cycling in these soils, or containing more information about the soils, as well as more detailed discussion of ${ }^{14} \mathrm{C}$ data with regard to soil carbon dynamics at each site, are also listed.

\section{RESULTS}

Tables 2 and 3 show the carbon and ${ }^{14} \mathrm{C}$ content of the fractionated SOM. To better compare the effects of fractionation methods on the different soils, the results are also plotted in Figures 2 and 3.

\section{Density Separation}

Low-density components consist primarily of fine root hairs, charcoal (found in most LD fractions, but not quantified separately) and surface detritus mixed into the soil (in Oxisols BS-7, BS-9). Lowdensity material makes up a large portion of the total soil carbon in A horizons of more coarse-textured soils and the Andisol (which also had the highest total carbon content, Table 2). The ${ }^{14} \mathrm{C}$ content of $\mathrm{LD}$ material is close to atmospheric ${ }^{14} \mathrm{CO}_{2}$ values at the time of collection in both pre- and post-bomb soils, indicating rapid turnover of this fraction.

In general, ${ }^{14} \mathrm{C}$ values of the dense fraction (mineral-associated) carbon decreased with depth in the soil, as has been observed (Scharpenseel et al. 1989). A notable exception is in the Spodosol Bs horizon (where sesquioxide accumulation is occurring), which shows increased ${ }^{14} \mathrm{C}$ values compared to the overlying elluvated horizon. Bomb ${ }^{14} \mathrm{C}$ is present in $\mathrm{HD}$ fraction for soils sampled in the $1990 \mathrm{~s}$, indicating the presence of at least some fast-cycling carbon associated with soil mineral phases.

\section{Acid-Base Hydrolysis}

In the heavier-textured soils (excluding the Shaver soil from the Sierra Nevada, California), most of the carbon present is associated with mineral surfaces (HD fraction). Hydrolysis of the HD fraction in relatively mild acids $(0.5 \mathrm{~N} \mathrm{HCl})$ removes $>30 \%$ of the mineral-associated carbon for all soils studied (see Fig. 2A). The removal is greatest in Spodic B horizons (the Michigan soils samples, B1-56 and A1-52), where $>70 \%$ of the organic carbon is solubilized in $0.5 \mathrm{~N} \mathrm{HCl}$. The carbon remaining is depleted in ${ }^{14} \mathrm{C}$ compared to the starting dense fraction material to varying degrees (Fig. 3A). Least affected are the Andisol (Hawaii) samples; most affected are the spodic B horizons. Subsequent hydrolysis in base and strong acid removes more carbon and ${ }^{14} \mathrm{C}$ (Figs. $2 \mathrm{~B}$ and $3 \mathrm{~A}-\mathrm{C}$ ). The residue after $\mathrm{A}+\mathrm{B}+\mathrm{C}$ treatments is, in all but two cases, the most depleted in ${ }^{14} \mathrm{C}$ of any treatment. Figure 3 summarizes the difference in ${ }^{14} \mathrm{C}$ content of residual carbon after various treatments, compared to the starting dense material (1:1 line on figures). The $A+B$ treatment (Fig. 3B) removes almost as much carbon and ${ }^{14} \mathrm{C}$ as the $\mathrm{A}+\mathrm{B}+\mathrm{C}$ treatment, while treatments using only acids $(\mathrm{A}+\mathrm{C} ; \mathrm{Fig} .3 \mathrm{C}$ ) do not remove as much $\mathrm{C}$ and ${ }^{14} \mathrm{C}$ as treatments including a base hydrolysis step. The Andisols and Oxisols are affected by chemical fractionation less than coarser-textured soils. The difference between unfractionated dense material and the $\mathrm{A}+\mathrm{B}$ or $\mathrm{A}+\mathrm{B}+\mathrm{C}$ residues is smaller in $\mathrm{A}$ horizons of soils than in $\mathrm{B}$ horizons. This is more noticeable in previously published profiles (Trumbore, Bonani and Wölfli 1990). 

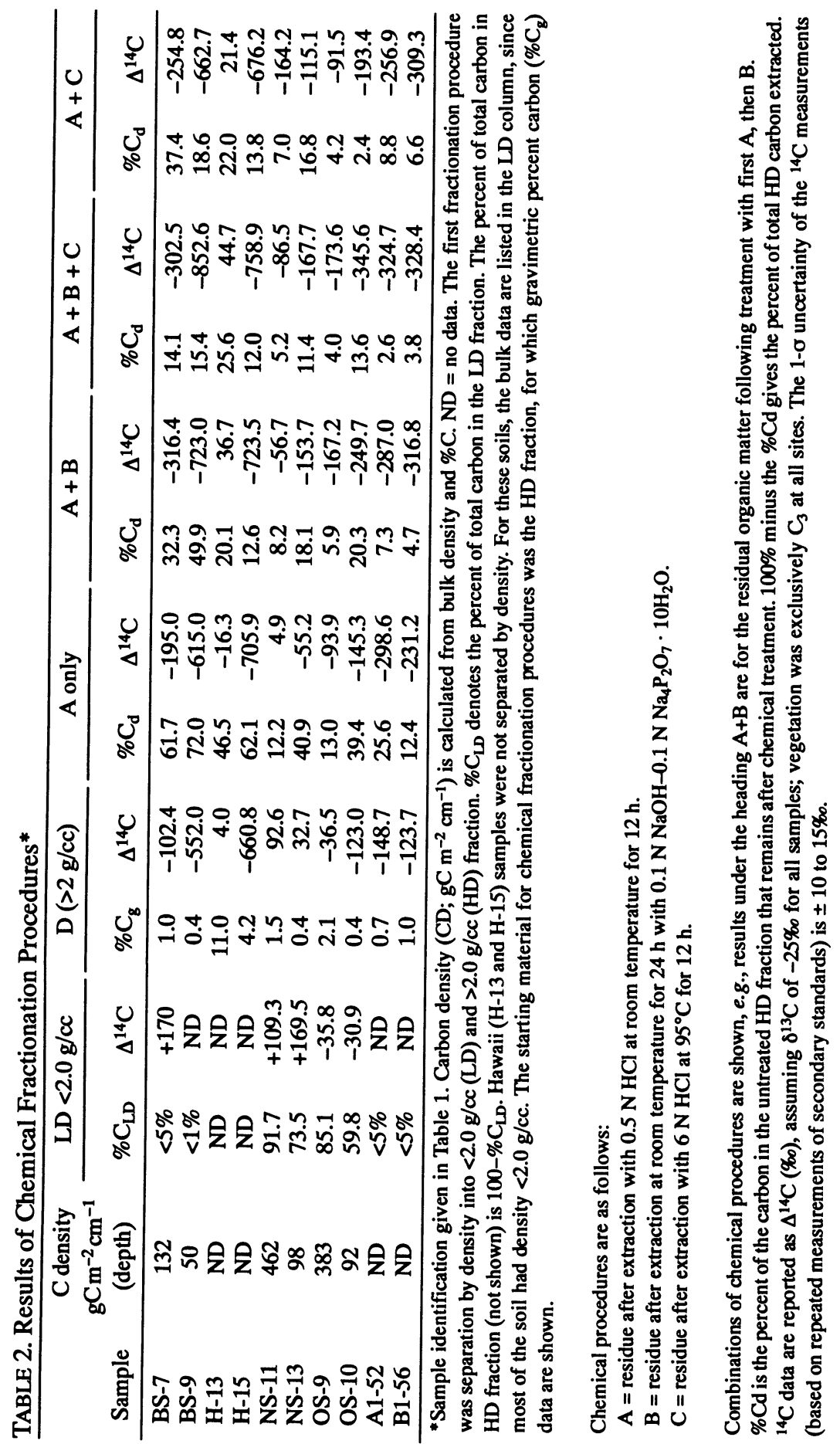
A. Carbon in Chemical Fractions

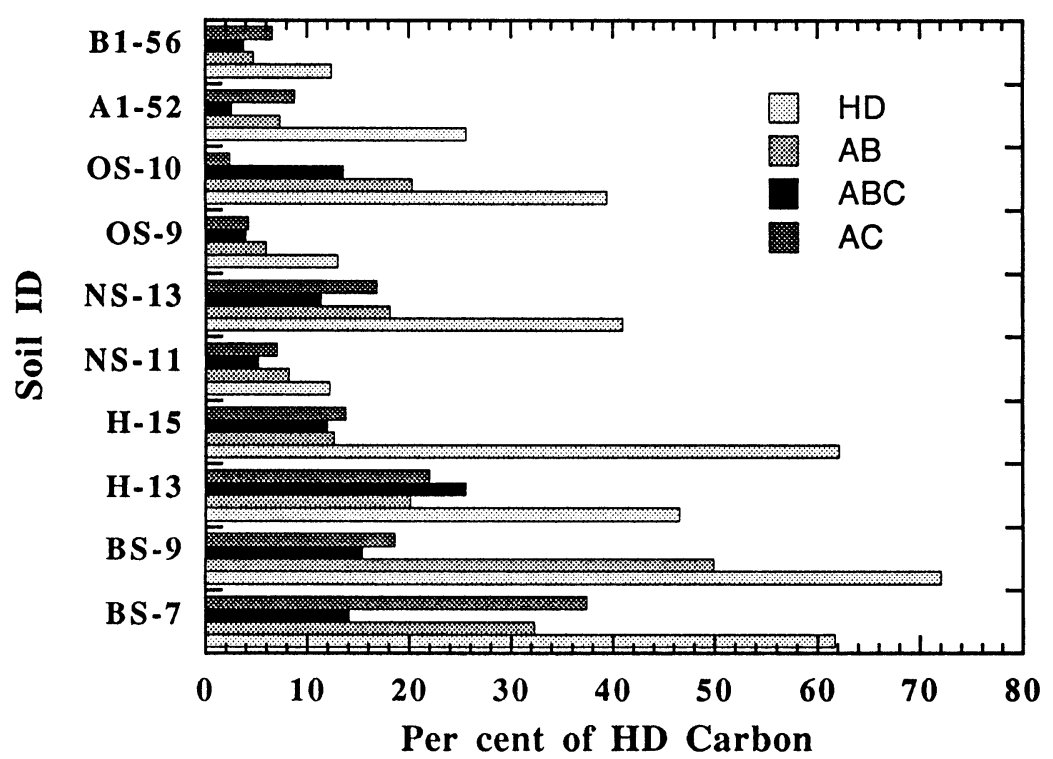

B. Carbon Distribution by Size

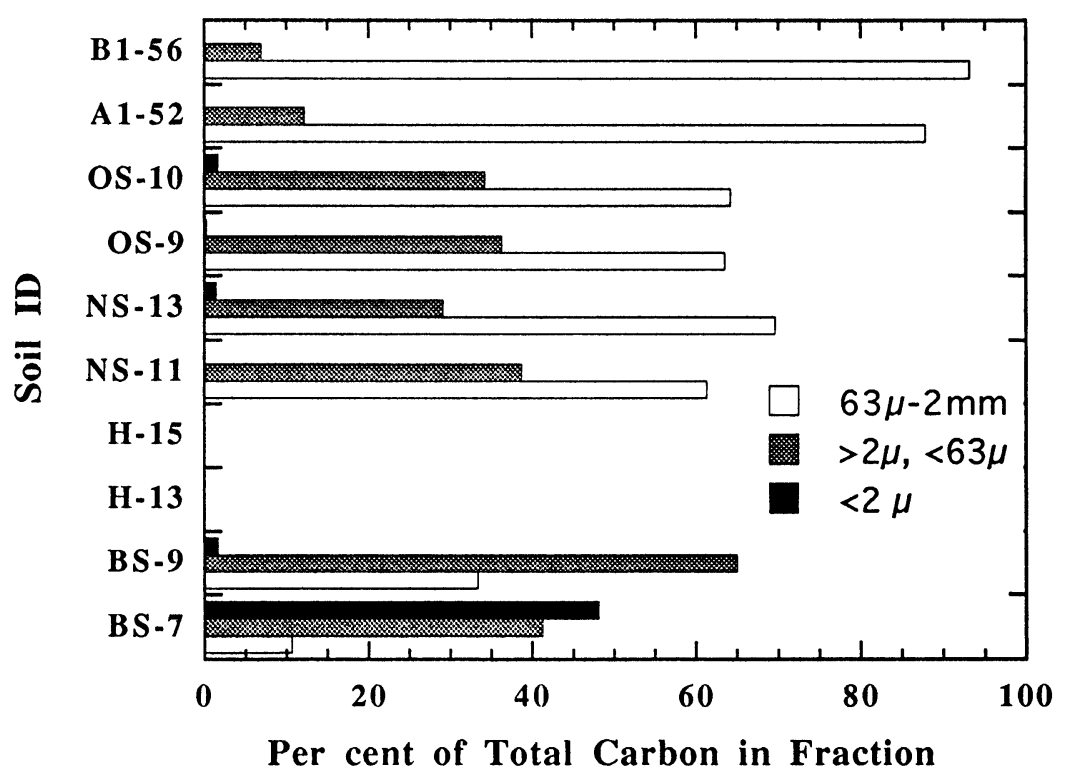

Fig. 2. Percent of total carbon in the residues left after acid and base hydrolysis treatments of the dense fraction (A) and after size fractionation of the bulk soil (B). 
TABLE 3. Results of Size Fractionation Procedures*

\begin{tabular}{|c|c|c|c|c|c|c|c|c|c|}
\hline \multirow[b]{2}{*}{ Sample } & \multicolumn{3}{|c|}{$2 \mathrm{~mm}>\mathrm{S}>63 \mu$} & \multicolumn{3}{|c|}{$63 \mu>S>2 \mu$} & \multicolumn{3}{|c|}{$>2 \mu$} \\
\hline & $\% \mathrm{C}$ & $\% \mathrm{Ct}$ & $\Delta{ }^{14} \mathrm{C}$ & $\% \mathrm{C}$ & $\% \mathrm{Ct}$ & $\Delta^{14} \mathrm{C}$ & $\% \mathrm{C}$ & $\% \mathrm{Ct}$ & $\Delta^{14} \mathrm{C}$ \\
\hline BS-7 & 3.9 & 10.6 & 7.6 & 1.5 & 41.3 & -92.5 & 1.0 & 48.1 & -107.4 \\
\hline BS-9 & 0.4 & 33.3 & -465.8 & 0.4 & 65.0 & -499.7 & 0.5 & 1.6 & -368.6 \\
\hline NS-11 & 11.2 & 61.3 & 82.9 & 3.5 & 38.7 & 67.5 & -- & -- & -- \\
\hline NS-13 & 0.8 & 69.5 & 11.0 & 1.7 & 29.1 & 41.7 & 4.5 & 1.4 & 73.8 \\
\hline OS-9 & 2.2 & 63.5 & -54.4 & 4.7 & 36.3 & -41.5 & 7.8 & 0.2 & -55.1 \\
\hline OS-10 & 0.9 & 64.2 & -108.1 & 1.8 & 34.2 & -51.6 & 2.9 & 1.6 & -271.3 \\
\hline A1-52 & 0.6 & 87.8 & -128.8 & 12.6 & 12.2 & -103.0 & $\begin{array}{l}\text { Very little } \\
\text { clay }\end{array}$ & & \\
\hline B1-56 & 0.6 & 93.1 & -113.3 & 15.2 & 6.9 & -91.6 & $\begin{array}{c}\text { Very little } \\
\text { clay }\end{array}$ & & \\
\hline
\end{tabular}

${ }^{*} \% \mathrm{C}$ is gravimetric carbon content, \%Ct is the percent of total soil carbon in the size fraction and ${ }^{14} \mathrm{C}$ data are reported as $\Delta^{14} \mathrm{C}(\% 0)$, assuming $\delta^{13} \mathrm{C}$ values of $-25 \%$ for all samples.
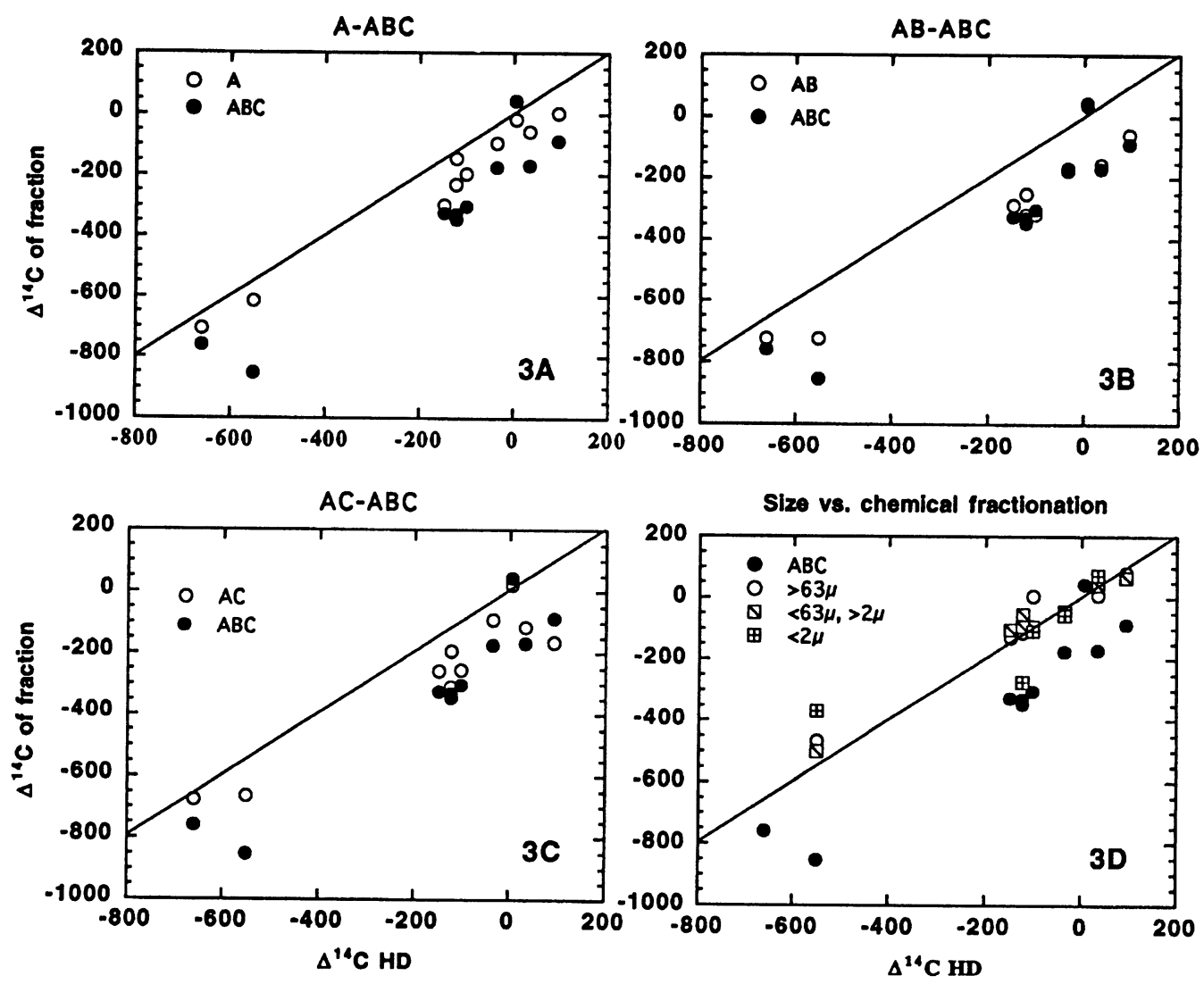

Fig. 3. $\Delta^{14} \mathrm{C}$ of the dense fraction (HD) compared to that measured in the residue after various chemical treatments. The 1:1 line (which signifies no difference in ${ }^{14} \mathrm{C}$ between the residue and the untreated original material) and the $\Delta^{14} \mathrm{C}$ values for $\mathrm{A}+\mathrm{B}+\mathrm{C}$ treatments (normally the most ${ }^{14} \mathrm{C}$-depleted residues) are shown on each figure. 


\section{Size Fractionation}

The results of size fractionation on splits of the same soils in which density and chemical procedures were used are reported in Table 3 . Most of the carbon in coarser-textured soils was associated with the $>63 \mu$ fraction (Fig. 2B), whereas in more clay-rich, heavy-textured soils (Oxisols), most of the organic carbon is associated with the fine silt and clay fractions $(<63 \mu)$. Size separations were not performed on the Andisol (Hawaii) soils; these are dominated by fine-grained material. Size-fractionation of soils did not affect ${ }^{14} \mathrm{C}$ values as much as chemical fractionation (Fig. 3D). We did not see any consistent tendency for clay-sized particles to have $\Delta^{14} \mathrm{C}$ values much greater or less than other size fractions, although clay fractions both enriched and depleted in ${ }^{14} \mathrm{C}$ were observed.

\section{SUGGESTIONS FOR A STANDARD FRACTIONATION SCHEME}

The usefulness of different fractionation methods depends in part on the type of soil, in particular, on soil texture (clay content). Separation by density will concentrate organic matter that turns over rapidly (decades and shorter time scales) in the low-density fraction. In coarse-textured soils with granitic parent material, such as the Shaver soil (Sierra Nevada), low-density organic matter can make up the majority of the total soil carbon in the A horizon. The remaining HD material shows significant ${ }^{14} \mathrm{C}$ increases in $\mathrm{A}$ horizons due to incorporation of bomb ${ }^{14} \mathrm{C}$. Chemical treatment, especially hydrolysis in acid and base, removes relatively ${ }^{14} \mathrm{C}$-enriched components of the dense, mineral-associated organic matter. Chemical treatment is most effective in coarse-textured soils, in part because more of the total carbon is removed in the hydrolysis procedure. Chemical extraction with acids and bases did not change the ${ }^{14} \mathrm{C}$ content of Andisol organic matter, even though up to 90 $95 \%$ of the original carbon was removed.

Large differences in ${ }^{14} \mathrm{C}$ content were not observed between different size fractions. Most of the carbon in coarse-textured soils is in the larger size fractions $(>63 \mu)$, and probably is mostly low-density vascular plant material, although ${ }^{14} \mathrm{C}$ values indicate that this organic matter is diluted by other (mineral associated) constituents.

We suggest the most informative fractionation procedure to be used in separating SOM into faster and slower cycling components combines density and chemical separation procedures. Low-density organic material (except for charcoal) turns over on timescales of decades and less (Trumbore 1993; Trumbore, Chadwick and Amundson 1996). Extraction of dense material with acid and base will leave a residue that can provide a minimum estimate of the size and ${ }^{14} \mathrm{C}$ content of a passive pool in ${ }^{14} \mathrm{C}$ modeling. This fractionation will be most useful in soils of medium-to-coarse texture, with granitic parent material.

\section{ACKNOWLEDGMENTS}

This research was undertaken as part of projects funded by NASA's Terrestrial Ecology and Earth Science Programs and a grant from the A. W. Mellon Foundation. We are extremely grateful to John Southon, Michaele Kashgarian, Jay Davis, and others at the Center for Accelerator Mass Spectrometry of Lawrence Livermore National Laboratory for continued rapid throughput of ${ }^{14} \mathrm{C}$ AMS samples.

\section{REFERENCES}

Anderson, D. W. and Paul, E. A. 1984 Organomineral complexes and their study by radiocarbon dating. Soil Science Society of America Journal 48: 298-301.

Balesdent, J. 1987 The turnover of soil organic fractions estimated by radiocarbon dating. The Science of the Total Environment 62: 405-408.

Barrett, L. R. and Schaetzl, R. J. 1992 An examination of podzolization near Lake Michigan using chronofunc- 
tions. Canadian Journal of Soil Science 72: 527-541.

Buchanan, D. L. and Corcoran, B. J. 1959 Sealed-tube combustions for the determination of carbon-13 and total carbon. Analytical Chemistry 31: 1635-1637.

Cambardella, C. A. and Elliott, E. T. 1993 Carbon and nitrogen distribution in aggregates from cultivated and native grassland soils. Soil Science Society of America Journal 57: 1071-1076.

1994 Carbon and nitrogen dynamics of SOM fractions from cultivated grassland soils. Soil Science Society of America Journal 58: 123-130.

Campbell, C. A., Paul, E. A., Rennie, D. A. and McCallum, K. J. 1967 Applicability of the carbon-dating method of analysis to soil humus studies. Soil Science 104: 217-224.

Davidson, E. A. and Ackerman, I. L. 1993 Changes in soil carbon inventory following cultivation of previously untilled soil. Biogeochemistry 20: 161-194.

Donahue, D. J., Linick, T. W. and Jull, A. J. T. 1990 Isotope-ratio and background corrections for accelerator mass spectrometry radiocarbon measurements. $R a$ diocarbon 32(2): 135-142.

Ertel, J. M. and Hedges, J. I. 1984 Source of sedimentary humic substances: Vascular plant debris. Geochimica et Cosmochimica Acta 49: 2097-2107.

Folk, R. L. 1961 Petrology of Sedimentary Rocks. Austin, Texas, Hemphill's: 142 p.

Gillespie, R., Hammond, A. P., Goh, K. M., Tonkin, P. J., Lowe, D. C, Sparks, R. J and Wallace, G. 1992a AMS dating of a late Quaternary tephra at Graham Terrace, New Zealand. Radiocarbon 34(1): 21-27.

Gillespie, R., Prosser, I. P., Dlugokenky, E., Sparks, R. J., Wallace, G. and Chappell, J. M. A. 1992b AMS dating of alluvial sediments on the southern tablelands of New South Wales, Australia. Radiocarbon 34(1): 2936.

Goh, K. M., Stout, J. D. and O'Brien, B. J. 1984 The significance of fractionation dating in dating the age and turnover of SOM. New Zealand Journal of Soil Science 35: 69-72.

Goh, K. M., Stout, J. D. and Rafter, T. A. 1977 Radiocarbon enrichment of soil organic matter fractions in New Zealand soils. Soil Science 123: 385-391.

Goh, K. M., Rafter, T. A., Stout, J. D. and Walker, T. W. 1976 The accumulation of SOM and its carbon isotope content in a chronosequence of soils developed on aeolian sand in New Zealand. New Zealand Journal of Soil Science 27: 89-100.

Hammond, A. P., Goh, K. M., Tonkin, P. J. and Manning, M. R. 1991 Chemical pretreatments for improving the radiocarbon dates of peats and organic silts in a gley podzol environment-Grahams Terrace, North Westland, New Zealand. New Zealand Journal of Geology and Geophysics 34: 191-194.

Harkness, D. D., Harrison, A. F. and Bacon, P. J. 1986 The temporal distribution of "bomb" ${ }^{14} \mathrm{C}$ in a forest soil. In Stuiver, M. and Kra, R., eds., Proceedings of the 12th International Radiocarbon Conference. $\mathrm{Ra}$ diocarbon 28(2A): 328-337.
Harrison, K., Broecker, W. and Bonani, G. 1993 A strategy for estimating the impact of $\mathrm{CO}_{2}$ fertilization on soil carbon storage. Global Biogeochemical Cycles 7: 69-80.

Jenkinson, D. J., Adams, D. E. and Wild, A. 1991 Model estimates of $\mathrm{CO}_{2}$ emissions from soil in response to global warming. Nature 351: 304-306.

Jenkinson, D. J. and Raynor, J. H. 1977 The turnover of SOM in some of the Rothamsted classical experiments. Soil Science 123: 298-305.

Martel, Y. A. and Paul, E. A. 1974 The use of radiocarbon dating of organic matter in the study of soil genesis. Soil Science Society of America Proceedings 38: 501506.

Mayer, L. M. 1994 Relationships between mineral surfaces and organic carbon concentrations in soils and sediments. Chemical Geology 114: 347-363.

Oades, J. M. 1993 The role of biology in the formation, stabilization and degradation of soil structure. Geoderma 56: 377-400.

O'Brien, B. J. and Stout, J. D. 1978 Movement and turnover of SOM as indicated by carbon isotopic measurements. Soil Biology and Biochemistry 10: 309-317.

Parton, W. J., Schimel, D. S., Cole, C. V. and Ojima, D. S. 1987 Analysis of factors controlling soil organic matter levels in Great Plains grasslands. Soil Science Society of America Journal 51: 1173-1179.

Paul, E. A., Campbell, C. A., Rennie, D. A. and McCallum, K. J. 1964 Investigations of the dynamics of soil humus utilizing carbon dating techniques. In Transactions of the 8th International Congress of Soil Science. Bucharest, Academy of the Socialist Republic of Romania: 201-208.

Potter, C. S., Randerson, J. T., Field, C. B., Matson, P. A., Vitousek, P. M. and Mooney, H. A. 1993 Terrestrial ecosystem production: A process model based on global satellite and surface data. Global Biogeochemichal Cycles 7: 811-842.

Scharpenseel, H. W. and Becker-Heidmann, P. 1992 Twenty-five years of radiocarbon dating soils: Paradigm of erring and learning. In Long, A. and $\mathrm{Kra}, \mathrm{R}$. S., eds., Proceedings of the 14 th International ${ }^{14} \mathrm{C}$ Conference. Radiocarbon 34(3): 541-549.

Scharpenseel, H. W., Becker-Heidmann, P., Neue, H. U. and Tsutsuki, K. 1989 Bomb-carbon, ${ }^{14} \mathrm{C}$ dating and ${ }^{13} \mathrm{C}$ measurements as tracers of organic matter dynamics as well as of morphogenic and turbation processes. The Science of the Total Environment 81/82: 99-110.

Scharpenseel, H. W., Ronzani, C. and Pietig, F. 1968 Comparative age determinations on different humicmatter fractions. In Proceedings of the Symposium on the Use of Isotopes and Radiation in Soil Organic Matter Studies. IAEA, Vienna: 67-74.

Schimel, D. S., Braswell, B. H., Holland, E. A., McKeown, R., Ojima, D. S., Painter, T. H., Parton, W. A. and Townsend, A. R. 1994 Climatic, edaphic and biotic controls over storage and turnover of carbon in soils. Global Biogeochemical Cycles 8: 279-294.

Sollins, P., Spycher, G. and Topik, C. 1983 Processes of 
soil organic matter accretion at a mudflow chronosequence, Mt. Shasta, California. Ecology 64: 12731282.

Southon, J. R., Vogel, J. S., Trumbore, S. E., Davis, J. C., Roberts, M. L., Caffee, M. W., Finkel, R. C., Proctor, I. D. Heikkinen, D. W., Berno, A. J. and Hornady, R. S. 1992 Progress in AMS measurements at the LLNL spectrometer. In Long, A. and Kra, R. S., eds., Proceedings of the 14 th International ${ }^{14} \mathrm{C}$ Conference. $R a$ diocarbon 34(3): 473-477.

Spycher, G., Sollins, P. and Rose, S. 1983 Carbon and nitrogen in the light fraction of a forest soil: Vertical distribution and seasonal patterns. Soil Science 135: 7987.

Stuiver, M., and Polach, H. A. 1977 Discussion: Reporting of ${ }^{14} \mathrm{C}$ data. Radiocarbon 19(3): 355-363.

Townsend, A. R., Vitousek, P. M. and Trumbore, S. E. 1995 Soil organic matter dynamics along gradients of temperature and land-use on the Island of Hawai'i. Ecology 76: 721-733.

Trumbore, S. E., Vogel, J. S. and Southon, J. R. 1989 AMS ${ }^{14} \mathrm{C}$ measurements of fractionated soil organic matter: An approach to deciphering the soil carbon cycle. In Long, A., Kra, R. S. and Srdox, D., eds., Proceedings of the 13th International ${ }^{14} \mathrm{C}$ Conference. $\mathrm{Ra}$ diocarbon 31(3): 644-654.

Trumbore, S. E. 1993 Comparison of carbon dynamics in two soils using measurements of radiocarbon in preand post-bomb soils. Global Biogeochemical Cycles
7: 275-290.

Trumbore, S. E., Bonani, G. and Wölfli, W. 1990 The rates of carbon cycling in several soils from $\mathrm{AMS}{ }^{14} \mathrm{C}$ measurements of fractionated soil organic matter. In Bouwman, A. F., ed., Soils and the Greenhouse Effect. Chichester, England, John Wiley \& Sons: 405-414.

Trumbore, S. E., Chadwick, O. A. and Amundson, R. 1996 Rapid exchange of soil carbon and atmospheric $\mathrm{CO}_{2}$ driven by temperature change. Science 272: 393396.

Trumbore, S. E., Davidson, E. A., Camargo, P. B., Nepstad, D. C. and Martinelli, L. A. 1995 Belowground cycling of carbon in forests and pastures of Eastern Amazonia. Global Biogeochemical Cycles 9: 515528.

Trumbore, S. E. and Druffel, E. R. M. 1995 Carbon isotopes for characterizing sources and turnover of nonliving organic matter. In Zepp, R. E. and Sonntag, Ch., eds., The Role of Non-Living Organic Matter in the Global Carbon Cycle. Berlin, John Wiley \& Sons: 722.

Vitorello, V. A., Cerri, C. C., Andreaux, F., Feller, C. and Victória, R. L. 1989 Organic matter and natural carbon-13 distribution in forested and cultivated oxisols. Soil Science Society of America Journal 53: 773-778.

Vogel, J. S. 1992 A rapid method for preparation of biomedical targets for AMS. In Long, A. and Kra, R. S., eds., Proceedings of the 14th International ${ }^{14} \mathrm{C}$ Conference. Radiocarbon 34(3): 344-350. 